\title{
Can an Anthropocene Series be defined and recognised?
}

\author{
JAN ZALASIEWICZ1, MARK WILLIAMS¹ ${ }^{1}$, COLIN N. WATERS²
}

1. Department of Geology, University of Leicester, University Road, Leicester LE1 7RH, UK.

\section{British Geological Survey, Keyworth, Nottingham, NG12 5DP, UK}

Abstract: We consider the Anthropocene as a physical, chronostratigraphic unit across terrestrial and marine sedimentary facies, from both a present and a far future perspective, provisionally using a $1950 \mathrm{CE}$ base that approximates with the 'Great Acceleration' of Steffen et al. (2007), worldwide sedimentary incorporation of A-bomb-derived radionuclides and light nitrogen isotopes linked to the growth in fertilizer use, and other markers. More or less effective recognition of such a unit today (with annual/decadal resolution) is faciesdependent and variably compromised by the disturbance of stratigraphic superposition that commonly occurs at geologically brief temporal scales, and that particularly affects soils, deep marine deposits and the pre-1950 parts of current urban areas. The Anthropocene, thus, more than any other geological time unit, is locally affected by such blurring of its chronostratigraphic boundary with Holocene strata. Nevertheless, clearly separable representatives of an Anthropocene Series may be found in lakes, land ice, certain river/delta systems, in the widespread dredged parts of shallow marine systems on continental shelves and slopes and in those parts of deepwater systems where human-rafted debris is common. From a far future perspective, the boundary is likely to appear geologically instantaneous and stratigraphically significant.

Keywords: Anthropocene, chronostratigraphy, sedimentary facies 
33 The concept that we may be living in an Anthropocene geological time interval 34 has attracted considerable interest and scrutiny since its latest restatement by Crutzen \& Stoermer (2000) and Crutzen (2002) (see also Revkin 1992). These authors effectively regarded the Holocene as having terminated because of the scale and significance of human impact upon the Earth System. In this view, a new and distinct phase of Earth history has already begun, and Crutzen in 2002 regarded the beginning of the Industrial Revolution as marking the beginning of profound global change.

Formalizing this concept within the Geological Time Scale (Zalasiewicz et al. $2008,2011,2012$ ) would result in the creation of an Anthropocene Epoch. Higher levels (e.g. Period, Era) might be considered because of the lack of precedent in Earth history for some of the component stratigraphical signals, such as the lithostratigraphical signal in urban regions (Price et al. 2011, Ford et al. this volume) and the scale and character of the biotic change (Barnosky 2008, this volume; Barnosky et al. 2011, 2012). Lower hierarchical levels are possible too (e.g. an Anthropocene Age as subdivision of the Holocene Epoch), and this would result in less modification of the Geological Time Scale. However, we continue to discuss the Anthropocene in terms of the hierarchical level of Epoch, not least because it brings clear focus on the important scientific question of whether or not the Earth system now lies outside of the 'Holocene envelope' of stratigraphically significant environmental conditions (cf. Röckstrom et al. 2009; Steffen et al. 2011).

\section{Anthropocene boundary level}

59

60 To carry out the analysis below, we must provisionally select a start date for the Anthropocene. Potential dates for the beginning of this phenomenon have fallen into three categories. Firstly, dates a few to several millennia back within the Holocene (Certini \& Scalenghe; Ruddiman 2013) have been suggested, reflecting the growing evidence for widespread, low-intensity human modification of the 
controversially (Ruddiman 2003, 2013; cf. Elsig et al. 2009) resultant release of sufficient greenhouse gases to maintain the Holocene within stable conditions of climate and sea level. Secondly, the beginning of the Anthropocene at 1800 CE, as originally suggested by Crutzen (2002): that is, around the beginning of the Industrial Revolution when the rapid increase in human numbers, energy use and atmospheric carbon dioxide levels began (Zalasiewicz et al. 2008, Fig. 1). And thirdly $1950 \mathrm{CE}$, the beginning of the post-war 'Great Acceleration' of economic activity (Steffen et al. 2007).

We regard the latter two as the more suitable candidates, because of the clear break between Holocene global stability (or very slow change) and the more rapid and geologically striking changes of the last two centuries (e.g. Zalasiewicz et al. 2008, Fig. 1; Steffen et al., 2011, Fig. 1). The Anthropocene does not represent the detectable incoming of human influence (which in any case is clearly diachronous: e.g. Kaplan et al. 2011) but major change to the Earth system, that happens to be currently driven by human forcing, but that may geologically soon be more significantly controlled by a number of secondary positive feedbacks such as methane release from permafrost and ice-albedo changes (e.g. Hay 2013, pp. 897-939).

For the purposes of this exercise we choose the later, 1950 CE date. This level coincides with changes to lacustrine dynamics and sedimentation worldwide (expressly linked to a potential Holocene/Anthropocene boundary by Wolfe et al. 2013, and partly reflecting worldwide shift in nitrogen isotopes associated with increase in global fertilizer use: Holtgrieve et al. 2011). It also coincides with the beginning of the nuclear age and the spread of artificial radionuclides into contemporary sediments worldwide, and both biotic (Barnosky, this volume, Wilkinson et al., this volume) and physical (Ford et al., this volume) stratigraphical signals that seem to be both stratigraphically sharp (to decadal level) and globally widespread. These changes are traceable by scientists living today, and not just by hypothetical 'far-future' geologists. They represent a significant and permanent shift in the Earth system, though likely not the 
129 Separate geological time scales have been set up for other bodies such as the 130

greatest changes, that will almost certainly take place in the coming centuries and millennia (Barnosky et al. 2011, 2012; New et al. 2011).

Thus, while it is still too early to make a formal recommendation, the $\sim 1950$ level currently seems to provide sharper stratigraphic definition than the relatively more diffuse and diachronous signals associated with the Industrial Revolution (e.g. the shift in carbon isotopes from the increase in fossil fuel burning: Al-Rousan et al. 2004).

We do not here examine the question of whether the boundary should be defined by a Global Standard Stratigraphic Age (GSSA or more simply a numerical age) or Global Stratigraphic Section and Point (GSSP = 'golden spike'). For practical purposes in current use, we consider that either would be effective. By whichever means defined, this $\sim 1950$ CE level might be regarded as stratigraphically challenging, in encompassing (to date) the geologically almost infinitesimally brief interval of $\sim 65$ years: over three orders of magnitude shorter than the Holocene and over five orders of magnitude shorter than the average epoch in the Cenozoic (Fig. 1).

\section{The Anthropocene in geochronology and chronostratigraphy}

Given current stratigraphic practice, we must consider the Anthropocene as a potential formal stratigraphic unit in not one but two meanings.

Firstly, it is a potential geochronological unit, that is, one of geological time, over which a variety of events have taken place on Earth. An Anthropocene Epoch, as an Earth-based time unit, would (as with the Holocene Epoch and all other geochronological units) hence be used as temporal reference for events in the Earth's deep interior as much as those at the surface.

\footnotetext{
Moon and Mars (Tanaka \& Hartmann 2012) and so an Anthropocene Epoch
} 
131 would be limited to this planet, as holds currently true for other terrestrial

132 geochronological units. The limits on Earth extend from the core to the

133 atmosphere and arguably to the region of space immediately dominated by the

134 Earth's gravitational field, though excluding the Moon, that has a separate

135 stratigraphic scheme (Tanaka \& Hartmann 2012). However, we note that it is

136 now beginning to be possible to correlate the Anthropocene across space, in

137 what might be regarded as the first interplanetary stratigraphic marker since the

138 products of the Late Heavy Bombardment of the late Archaean. Infinitesimally

139 smaller in bulk though very much more synchronously distributed, human-

140 projected spacecraft and associated debris have now left physical traces on and

141 around several planets and moons of this Solar System.

142

143 For all past geological units, with the exception of the later part of the Holocene

144 Epoch (that we still, formally, live in) all of our knowledge of the history of the

145 Earth is derived from the rock record. From the beginning of a human written

146 record, this proxy record began to be augmented by human observations of

147 terrestrial events. This human observation has developed, today, to the extent

148 that many terrestrial processes are now routinely monitored, recorded and

149 analysed; this means that geological proxy data of the Anthropocene, being

150 captured within rock currently forming, can now be directly compared with the

151 geological events themselves.

152

153 The Anthropocene, in tandem with other geological units, should also be

154 considered as a material rock unit of chronostratigraphy (commonly referred to

155 as 'time-rock'). Chronostratigraphic units are commonly regarded as the

156 material 'rock' record of geological time, and thus the physical embodiment of

157 (and evidence for) the passage of time. Thus, the Jurassic System comprises all

158 of the rock formed during the Jurassic Period, while the Pleistocene Series is the

159 equivalent rock record of the Pleistocene Epoch. There is hence a hierarchical

160 system of chronostratigraphical terms, exactly parallel to those of

161 geochronology. The Anthropocene, if considered as an Epoch, should also be

162 considered as a Series.

163 
165 Chronostratigraphy, scale-dependence and the Anthropocene

166

167 Not all geologists consider chronostratigraphy to be a necessary and

168 fundamental part of the Geological Time Scale (e.g. Carter 2007; Zalasiewicz et

169 al. 2004, 2007). In such an interpretation there need not be both a Pleistocene

170 Epoch and a Pleistocene Series, but simply an Epoch, to which the material

171 record is referred descriptively (thus: strata formed during the Pleistocene

172 Epoch, or more simply 'Pleistocene strata'). Currently, though, most

173 stratigraphers, as represented by voting members of the International

174 Commission on Stratigraphy, prefer to use the dual hierarchy of geochronology +

175 chronostratigraphy (Zalasiewicz et al. 2013), and so we here regard

176 consideration of an Anthropocene Series as an integral part of the analysis of the

177 Anthropocene concept.

178

179 Chronostratigraphy in practice only effectively applies to stratified rocks, where

180 superposition applies and hence 'lower' equals 'older' and 'upper' equals

181 'younger' (Zalasiewicz et al. 2013). Single hand specimens of igneous and

182 (especially) metamorphic rocks commonly include a number of intermeshing

183 fabrics of distinctly different ages (that can be dated and placed within a

184 geochronological framework), and so 'upper' and 'lower' have no meaning and

185 the rock itself cannot be regarded as having 'formed' at a particular moment in

186 time. Thus, a putative Anthropocene Series encompasses only stratified deposits

187 currently accumulating and not (say) mineral assemblages now crystallizing (i.e

188 during the Anthropocene Epoch) in the roots of current mountain belts.

189

190 Chronostratigraphy is also scale-dependent (Zalasiewicz et al. 2007). That is, on

191 short time-scales, the superpositional fabrics of sedimentary stratification may

192 be disrupted by such processes as bioturbation (in marine deposits especially:

193 Anderson 2001) or by soil-forming processes (Bacon et al. 2012), giving

194 disrupted sedimentary fabrics in which temporal information has been mixed or

195 homogenized. This process commonly affects time units of durations of some

196 thousands of years (Anderson 2001) but it can also act over time scales of 
millions of years (e.g. Bacon et al. 2012) and length scales of kilometres in the case of subsurface sedimentary diapirism (e.g. Shoulders \& Cartright 2004).

200 For most stratigraphic units in the deep time record, this scale-dependence effect

201 may be neglected, given that currently achievable levels of time resolution are 202 typically measured in fractions of millions of years. However, the duration of 203 epochs, both actual (Holocene) and potential (Anthropocene) becomes much 204 shorter towards the present day (Fig. 1). Thus, for Pleistocene and (especially) 205 for Holocene strata the scale dependence effect becomes significant, and for the 206 Anthropocene (where decadal time resolution may reasonably be sought) it 207 becomes an important factor in chronostratigraphic definition.

\section{Components of an Anthropocene Series}

Despite the complications noted above, an attempt to define an Anthropocene

213 Series is both part of formal stratigraphic analysis and, independently of this, is

214 useful in helping to understand the Anthropocene phenomenon (formal or informal) as a part of Earth history.

217 What might an Anthropocene Series, and its various material stratigraphic 218 components, comprise? We consider the strata that accumulate in a range of 219 geographic settings, from terrestrial (in the sense of 'land-based') to deep 220 marine, and discuss how they might be recognised and characterised. We 221 reiterate that the Anthropocene here is a time boundary, and not a boundary 222 between anthropogenic 'artificial' and 'natural' sedimentary facies. Hence an 223 Anthropocene Series (and, indeed, pre-Anthropocene deposits) will include both 224 of these facies, the boundary between them being diachronous. Nevertheless, 225 the extent of facies diachroneity will vary, both geographically and between 226 different types of stratigraphic signal, and this might offer the possibility of 227 effective discrimination of an Anthropocene Series. 
These strata include a number of proxies for time - not least fossils, a form of evidence that remains key to the subdivision of Phanerozoic strata (Gradstein et al. 2012) and that has the potential to help characterise an Anthropocene interval (Barnosky, this volume; Wilkinson et al., this volume), when used in combination with other stratigraphic indicators (Waters et al., this volume).

\section{Terrestrial settings}

237

238 Geologically, the terrestrial realm may be divided into areas of erosion, 239 particularly of older rock, and areas of deposition. The former in stratigraphy 240 may be considered as unconformity surfaces, only to be preserved at the transition between phases of erosion and subsequent sedimentation. Although

242 such erosion surfaces may be studied by techniques such as Terrestrial

243 Cosmogenic Nuclide (TCN) dating (e.g. Gosse \& Phillips 2001), we will not

244 consider them further here, except via the indirect record they leave via the

245 sedimentary deposits eroded from them. These may be broadly categorized as

246 the following.

247

248 Soils: Soils are perhaps the most widespread terrestrial sedimentary facies,

249 forming on both erosional and depositional surfaces, and having deep time

250 equivalents, palaeosols, when preserved upon depositional surfaces.

252 The alteration of soils by anthropogenic activities is widespread, striking and

253 increasingly well documented (Richter, 2007). But, the spread of anthropogenic

254 soils has been strongly diachronous through the Holocene, and reflects the

255 spread of agriculture across the globe (Ellis et al. 2012). At present, therefore:

256 which soils are Holocene and which are Anthropocene?

257

258 One approach here has been to take a major phase of soil expansion two

259 thousand years ago across northern Europe (Certini \& Scalenghe 2011) and

260 suggest that the base of that may be taken as a 'golden spike' to mark the base of 261 the Anthropocene. This is an intriguing and imaginative suggestion, but is not 
262 without problems (Gale \& Hoare 2012). Firstly, the base of a soil upon older

263 regolith is gradational and cannot capture a boundary with the resolution

264 required for the Anthropocene. Secondly, and more generally, soils exemplify

265 the 'scale-dependence' phenomenon noted above, being continually reworked by

266 both natural and anthropogenic processes as long as they are at the Earth's

267 surface. Hence, it may in some ways be more appropriate to place all surface

268 soils in the Anthropocene, because they are continually being modified, even

269 though many of them have fabrics and components which range back for

270 thousands and, in some cases (Bacon et al. 2012) for millions of years. This

271 ongoing modification is arguably greatest for agricultural soils, because of the

272 intensive nature of human reworking. Because of the breakdown of

273 superposition, soils are generally problematic to classify chronostratigraphically

274 at the very high levels of temporal resolution required for the Anthropocene.

275 Thirdly, the criteria for definition of a 'golden spike' recommends that a section

276 be used in which there is a continuous succession, where observed gaps in

277 deposition are absent or at a minimum. In existing chronostratographical units,

278 palaeosols are considered to represent time-gaps and would be avoided as a

279 basis on which to define a chronostratigraphical boundary (Remane et al. 1996).

280

281 Lacustrine deposits: Lake deposits are perhaps the most straightforward to

282 deal with stratigraphically. Their deposits commonly form ordered strata, which

283 - especially in those lakes with low-oxygen bottom waters - tend not to be

284 seriously disrupted by bioturbation. The resulting high-resolution stratigraphic

285 archives can show a clear signal of the environmental changes that may

286 potentially characterise a 1950 CE Anthropocene Series base, such as

287 widespread, marked $\mathrm{N}$ isotope (Holtgrieve et al. 2011) and palaeontological

288 (Wolfe et al. 2013) signals in northern lakes far from urban centres, while the

289 incoming of A-bomb test-related radionuclides provides another marker

290 (Appleby 2008; Hancock et al. 2011; Yan et al. 2002; Hancock, this volume). If it

291 was decided to define the Anthropocene boundary via a physical reference level

292 or GSSP ('golden spike') rather than a designated numerical date GSSA (see

293 discussion below), then lake deposits will figure strongly as settings for

294 candidate stratotypes. Lacustrine sediments, though, include anthropogenic 
295 signals of other ages too, some markedly diachronous, such as sediment influxes associated with land use changes (Edwards \& Whittington 2001).

298 Fluvial deposits: The human management of rivers, and consequent alteration

299 of their patterns of sedimentation and erosion, has a long history, and the

300 consequent spread of indirect anthropogenic deposits has been marked (e.g.

301 Syvitski \& Kettner 2011; Merritts et al. 2011; Brown et al. 2013), multi-faceted

302 (e.g. the 19th century modification of fluvial sedimentation in north America, as

303 numbers of beavers - and hence beaver dams - fell sharply as a result of hunting:

304 Kramer et al. 2011) and strikingly diachronous across the world, and even in 305 part on a regional scale within the UK (Lewin 2012). Indeed, the difficulty of

306 consistently recognising an Anthropocene boundary in modern fluvial deposits 307 was regarded by Autin \& Holbrook (2012) as one reason to reject the concept of 308 a formalised Anthropocene.

However, globally, the rate of fluvial transformation saw significant rises that 311 coincided with the two main inflections in human economic activity at 1800 312 and at 1950 (Syvitski \& Kettner 2011) both of which are candidate dates for 313 the beginning of the Anthropocene. To what extent these may be generally 314 'traceable' within the sedimentary record seems still to be an open question. 315 Locally, at least, major, distinct Anthropocene bodies of sediment are building up 316 behind the major dams that in recent decades have been constructed on nearly 317 all major rivers of the world (Syvitski \& Kettner 2011), with rates of sediment 318 supply commonly increased by deforestation and related processes (Wilkinson, 319 2005). For instance, most sediment that used to be transported down to the Nile 320 Delta is now trapped behind the Aswan Dam (producing a substantial, and 321 rapidly growing Anthropocene sediment body) or held within artificially 322 multiplied (for irrigation) distributaries within a system that has been 323 completely altered by human activity (Stanley 1996).

325 Significant future rise in sea-level would be expected to result in development of 326 transgressive estuarine to marine deposits in the distal parts of river systems. 327 However, the interplay of associated changes in precipitation, vegetation and 
human forcing would certainly be complex, making patterns of sedimentation hard to predict.

Aeolian deposits Windblown deposits occur both within the major sand seas of the world, such as the ergs of the Sahara desert, as more localised dune fields, such as those associated with coastal areas, and also as far-travelled loess and related deposits. All are sensitive to local climate and to vegetation cover, and human activity, in particular through over-grazing, over-cultivation, unsustainable irrigation techniques and deforestation, which has strongly influenced the generation of loess through desertification, and whose effects include increases in dust flux (Goudie 2009). There is evidence of an increase of a factor of two in background dust loads over the Antlantic since the mid-1960's, the likely product of desertification caused by the doubling of the population in the Sahel region over the past 40 years (Moulin \& Chiapello 2006). The extent to which these might translate into an Anthropocene Series boundary is uncertain. It seems likely that within contemporary large, long-lived dune fields, at least, the shifting sands will render a boundary difficult to locate and trace precisely though in this the Anthropocene is not alone in facing difficulties of chronostratigraphic classification (see below).

Glacial deposits: Glacial deposits are sensitive recorders of changes in ice volume and extent, and many present-day glacial valleys in Europe include terminal moraines reflecting the greater extent of ice during the Little Ice Age of the $16^{\text {th }}$ to mid19th centuries (Mann 2002). Similarly, the shrinking of most mountain glaciers since the 1850's, with regional variations in both retreat and advance during the mid-20 th Century and large-scale retreats since the 1980's (IPCC 2001, figure 2.18.), linked to global temperature increases, has exposed morainic deposits that may be clearly identified and mapped as of Anthropocene age, particularly where detailed cartographic and photographic records occur of glacier extents earlier in the $20^{\text {th }}$ century (e.g. Kulkarni et al. 2007). Associated deposits include those laid down catastrophically by dam-bursts, as increased volumes of meltwater have accumulated behind and destabilized morainic dams and wasting morainic ice cores (Nayar 2009). 
362 Ice: This is also a terrestrial sedimentary deposit that is found on all the

363 continents (except in Australia, and probably not for much longer in Africa,

364 where it is represented only by rapidly-thawing Kilimanjaro). Ice sheets record

365 snow layers extending back many thousands of years, and encapsulating (in the

366 Arctic and Antarctic) the entire interval of human history, including levels that

367 can be identified for 1800 and 1950, and which provide data on rising $\mathrm{CO}_{2}$

368 intervals. Snow layers record human pollutants from the atmosphere back to

369 classical times (e.g. lead aerosols derived from Roman smelting). Following this,

370 there is a succession of recorded events that might provide geochemical criteria

371 to identify either a $\sim 1800 \mathrm{CE}$ or a $\sim 1950 \mathrm{CE}$ level. This includes the $\mathrm{CO}_{2}$ levels

372 preserved in air pockets (though this is compromised by the 'lock-in' time for air

373 post-dating the deposition of the snow). However, events such as the

374 appearance of nitrogen derived from the Haber-Bosch process (cf. Holtgrieve et

375 al. 2011), the change in lead isotopes reflecting the use and then abandonment of

376 lead additives in petrol (Bollhöfer \& Rosman 2000), and the incorporation of

377 artificial radionuclides provide useful global stratigraphic markers. The range of

378 palaeoenvironmental proxies recorded in this medium and the annual resolution

379 make selection of a GSSP within a snow/ice core a potential option, as for the

380 Pleistocene/Holocene boundary (cf. Walker et al. 2009).

382 Artificial deposits The transformation of primary raw materials (sand and

383 gravel, limestone, mudrock, metal ores) into the fabric of urban areas represents

384 the creation of a novel and substantial type of stratum in which the buildings

385 themselves and the associated landscape changes (the latter mapped as various

386 types of Artificial Ground on British Geological Survey maps, for instance: Price

387 et al. 2011; Ford et al. this volume) provide something that combines features of

388 a lithostratigraphic unit and of an extraordinarily large trace fossil system.

390 The resulting deposit is clearly anthropogenic but, because towns and cities have

391 been a feature of human civilization since the Epi-palaeolithic (Mesolithic) about

3929000 BC (see Edgeworth this volume), also clearly diachronous. We may discuss

393 two features of relevance here. 
395 Firstly, the extraordinary post-war growth of cities and megacities allows, by

396 simply mapping the historical growth of urban areas, a distinction between post-

$3971950 \mathrm{CE}$ artificial deposits and those that predate them (Fig. 2). Prior to the

398 1950's, large cities tended to be located close to natural resources or be suitable

399 coastal locations for the import/export of these resources. The post-1950s

400 evolution of megacities has relied upon the contained population of the megacity

401 to be the key resource, and these cities have been a centre for the inward influx

402 of natural resources sourced from rural areas and transported to the cities to

403 fuel industry and construction. This change can be seen as a product of

404 improvement of transport networks and greater efficiencies in the mass-

405 transport of bulk materials during the late $20^{\text {th }}$ century (Haff, this volume; see

406 also Williams et al., this volume). This creation of laterally continuous but

407 temporally distinct deposits may be compared with, say, those created naturally

408 during the progradation (outgrowth) of a delta system.

409

410 Secondly, even within the older parts of existing cities, the continuous

411 replacement of the urban fabric, both above and below ground, means that these

412 artificial deposits comprise complex mixtures of pre-Anthropocene and

413 Anthropocene rocks and minerals (and, locally, indeed fossils). The presence of

414 novel materials and minerals in both direct and to a lesser extent indirect

415 anthropogenic deposits (Ford et al. this volume, Zalasiewicz et al. this volume b)

416 provides an approach to dating these deposits to decadal level, a resolution far

417 beyond that applicable for previous epochs. This is a rather coarser-grained

418 equivalent of the situation noted above with soils, and again underscores the

419 awkwardness of chronostratigraphy in dealing with short time scales and

420 complex sedimentary processes and geometries. It is only towns and cities

421 abandoned pre-1950 that may be said to comprise wholly pre-Anthropocene

422 representatives of this deposit type.

423

424 Below ground, artificial ground locally deeply extends into underlying strata via

425 the many mineshafts and boreholes sunk to extract resources, with considerable

426 'halo' effects via such as hydrocarbon extraction (and now, injection of fluids and 
sand for shale gas extraction). Geologically, this is something of a hybrid, combining features of burrowing, albeit on an enormous scale, with those of intrusive bodies, showing cross-cutting relationships, and even of diagenetic alteration. Neither of the last two phenomena are generally classified within chronostratigraphic units (as they do not show superpositional relationships), as

432 their history may be protracted and only related in general terms to processes

433 acting at the Earth's surface (Ford et al. this volume). The subsurface

434 anthropogenic phenomena, by contrast, are very much related to surface activities (and can also impact on the surface, as for instance with acquaculturerelated subsidence on the Yellow River delta in China now reaches 250 mm/year: Higgins et al. 2013). They clearly form a pronounced and temporally constrained event, given the post-war surge in drilling and mining (Ford et al. this volume).

\section{Marine settings}

444 Coastal systems These systems include beaches, tidal flats and deltas.

445 Throughout much of the latter half of the Holocene, these have been commonly 446 progradational, as sediment eroded from the land, has accumulated around a 447 coastline more or less fixed as sea level stabilized following its post-glacial rise.

448 Where sediment has built up and built out in this way, then distinct stratal

449 packets that relate to industrialization and land use change have been

450 recognised and suggested as Anthropocene markers (e.g. Poirier et al. 2011).

451 Some are distinctive through their content of heavy metals, organic chemicals

452 and so on (e.g. Allen 1988; Marshall et al. 2007; Vane et al. 2011; Galuszka et al., 453 this volume), with eutrophication of coastal environments due to influx of excess 454 nitrogen, and these may also be used to help identify an Anthropocene/Holocene 455 boundary. Globally, the overall facies changes are diachronous, but within them 456 some signals (such as distinct chemical markers related to particular industrial 457 processes: Kruge 1999) may provide more or less synchronous marker levels. 458 
459 Within the last couple of centuries - and particularly the last several decades,

460 many coastal systems have seen large-scale change that is clearly relevant to the

461 historical characterisation of the Anthropocene, but that complicates the simple

462 progradational picture. For instance, as rivers have been dammed, sediment is

463 temporally stored behind the dams (see above) and does not nourish growing

464 deltas, some of which have as a consequence shrunk back (e.g. Nile, Mississippi

465 etc - Törnqvist et al. 2008). Related phenomena include the draining of coastal

466 wetlands for farmland, resulting in the large-scale loss of such strata as surface

467 peat deposits through desiccation, deflation and oxidation. For instance, some

$4682000 \mathrm{~km}^{2}$ of peat up to $4 \mathrm{~m}$ thick in the English Fenland alone has disappeared

469 since the $18^{\text {th }}$ century, resulting in the exposure of the underlying geology, now

470 itself compacted and oxidised (Smith et al. 2011). Attempts at stabilization of

471 coastal erosion rates through construction of coastal defences produces artificial

472 deposits, while impacting upon sediment flux and erosion rates adjacent to

473 protected regions. The Anthropocene boundary here approximates to a regional

474 sedimentary hiatus and disconformity - likely to be buried beneath new coastal

475 sedimentary deposits, a century or two hence, as only a geologically trivial sea

476 level rise will suffice to trigger marine transgression across such areas.

477

478 The expression of the Anthropocene in the environmentally sensitive coastal

479 systems, therefore, represents a diverse patchwork of deposits and lacunae that

480 reflect local interplays of natural and anthropogenic forces.

481

482 Shelf/slope marine systems Human impact on open marine systems has in 483 general substantially lagged those on land. The marine fisheries in northern 484 Europe began in earnest in Medieval times, perhaps as a result of technological 485 improvements (e.g. effective drift nets) and their spread across the world has 486 been charted by Roberts (2007). The concomitant, diachronous decline in fish 487 stocks through overfishing changed the structure of marine ecosystems, though 488 impacts on the kind of organisms (e.g. foraminifera, dinoflagellates - much lower 489 in the food chain) used in biostratigraphy have likely been small, even with the 490 dramatic fish declines reported (e.g. Myers \& Worm 2003). 
492 More profound physical and chemical impacts on recent marine strata are

493 associated with the industrial age, from $\sim 1800$ CE. The greatest physical impact

494 on sediments has been the physical disruption caused by sea bottom trawling.

495 This is not a modern technique: the $14^{\text {th }}$ century saw a petition to regulate the

496 use of the 'wondyrechaun' - essentially a wooden beam trawl used in shallow

497 coastal waters (Roberts 2007) - but open sea trawling came with steam-

498 powered ships, and has continued to expand markedly in recent decades, moving

499 into slope settings in waters approaching a kilometre deep.

500

501 Sea bottom trawling now affects some 15 million $\mathrm{km}^{2}$ each year (Gattuso et al.

502 2009) - representing most of the world's continental shelf area and also

503 including significant areas of deepwater slope (Puig et al. 2012) and seamount

504 surface. The process in effect ploughs the sea floor, producing a coarsening-

505 upwards sedimentary signature (Palanques et al. 2001; M. Coughlan, pers.

506 comm.), with mud swept up into an expanded nepheloid layer and transported

507 more distally, and nutrients redistributed (Dounas et al. 2007). Benthic

508 assemblages are altered (Malakoff, 2002) and some sensitive ones (e.g.

509 deepwater coral systems) effectively destroyed (Sheppard 2006). Topographic

510 effects may be substantial, with evident smoothing of topographic contours (Puig

511 et al. 2012).

512

513 More recent extension of 'Worked Ground' into a marine setting can be seen with

514 increased extraction of mineral resources including hydrocarbons and

515 aggregates. It is only since the 1940's that technology and economics has made

516 offshore extraction of hydrocarbons feasible and it has grown to the point where

517 it currently accounts for about $30 \%$ of total global output. Aggregate extraction

518 significantly modifies the marine landscape, causes habitat modification and

519 impacts on benthic communities both within, and downcurrent, of extraction

520 sites and can significantly change sediment fluxes, potentially starving supplies

521 of sand to coastal areas. Similar concerns are being raised about offshore wind

522 turbine construction, an even more recent and expanding innovation. 
524 Within tropical waters, bleaching of coral reefs in response to rising sea

525 temperatures, in addition to other stressors, such as increased turbidity of

526 marine waters due to runoff, the fishing process of dynamiting reefs and

527 ultimately decreasing ocean pH (Tyrrell 2011) may lead to the extinction of

528 whole reef systems, resulting in a drowned reef horizon.

529

530 In aggrading sedimentary systems, the resultant facies should have considerable

531 preservation potential. It is of limited diachroneity, given the marked post-1950

532 expansion of many of the processes involved.

533

534 Deep sea: This is usually considered as those areas where water is $>200 \mathrm{~m}$ deep

535 (i.e. largely below wave base and off the continental shelf edge) and might be

536 simplified into two main systems: the clastic wedges of turbidite fans and

537 contourite drifts that fringe the continental masses, and the slowly accumulating

538 deep-sea oozes that lie beyond. Both systems have been and continue to be

539 affected by physical disturbance (e.g. by trawling, offshore mineral extraction),

540 by input of particulate material ('litter') varying from micron to metre scale in

541 size (and locally indeed larger, in the case of shipwrecks), by chemical

542 contamination with both organic and inorganic substances, by effects associated

543 with atmospheric $\mathrm{CO}_{2}$ increase and warming (such as variations in $\mathrm{pH}$ and

544 dissolved oxygen content) and by biological changes driven by all of the above

545 processes, either directly or indirectly. The extent of these effects - all of which

546 can affect the nature of sediments being deposited - have been qualitatively

547 described but not yet rigorously mapped (Ramirez-Llodra et al. 2011). The

548 stratigraphic signal is patchy but locally may be striking. As with the effects of

549 urbanization, local signals go back millennia. Major expansions of activity and

550 hence extent of stratigraphic imprint were associated with the Industrial

551 Revolution at $1800 \mathrm{CE}$ and with the ongoing 'Great Acceleration' that started

$552 \sim 1950$ CE.

553

554 The accumulation of litter - material dropped overboard - has reached the level

555 where it rivals the extent of ice-rafted debris (IRD) in scale (Ramirez-Llodra et al.

556 2011), and is now seen in most surveys of the sea floor, where it is easily distinct 
557 from the surrounding (mostly very fine-grained) sediment. We suggest hence

558 terming this material, sedimentologically, as human-rafted debris (HRD) to help

559 characterize a deep-water facies of a putative Anthropocene Series. Given

560 technical progress, it shows the kind of extremely high-resolution

561 'biostratigraphy' of human artefacts and products also seen on land (Ford et al.,

562 this volume). Hence, spreads of clinker (combustion products from the coal that

563 powered steam-ships) were universally dumped on the sea floor in the period

$564 \sim 1800 \mathrm{CE}$ to $\sim 1950 \mathrm{CE}$, - now colonised by a specific biota - might be regarded

565 as immediately pre-Anthropocene in our provisional definition, while those with

566 plastics, aluminium and other such more modern materials largely date from

567 after 1950 CE (Ramirez-Llodra et al. 2011). In the distal, naturally slow-

568 accumulating parts of the sea floor, such HRD from different centuries will in

569 effect fall within and contribute to the same physical layer.

570

571 More broadly, within the clastic wedges, the pattern of turbidite/contourite

572 deposition seems not yet to have been substantially affected by human activity; it

573 is not clear that changes in sediment supply caused by large-scale anthropogenic

574 modification of river systems (e.g. Syvitski \& Kettner 2011) have yet filtered

575 down to cause substantial change to deep-sea clastic systems, though we regard

576 significant longer-term change as likely (see below). However, local effects

577 include the triggering of turbidity currents (that may also rework HRD into

578 concentrations: Ramirez-Llodra et al. 2011) by bottom trawling (Puig et al.

579 2012). In the longer-term, clastic shut-off caused by sea-level rise may be

580 envisaged.

581

582 The slowly accumulating deep-ocean oozes beyond will, in addition to such

583 accumulations, be influenced by anthropogenic change, via such signals as a

584 lighter carbon isotopic content in foraminifera shells, from the burning of fossil

585 fuels. Additional chemical signals such as those from anthropogenic organic

586 pollutants or artificial radionuclides are rapidly (e.g. Robison et al. 2005) if

587 unevenly (Buesseler et al. 2007) transported to the sea via aggregated sinking

588 planktonic debris. However, the very slow accumulation rate over most of this

589 realm means that this material is thoroughly intermixed, by bioturbation, with 
590 pre-Anthropocene sediment, precluding recognition at such scale of a distinct

591 Anthropocene Series. Only in regions of significantly more rapid deposition (e.g.

592 Al-Rousan et al. 2004) does such a potential Series emerge as a distinct entity

593 with coherent upper (sedimenting) and lower surfaces. However, potential

594 changes to ocean chemistry may result in more extensive anoxia, with eutrophic

595 bottom conditions limiting bioturbation, and changes to the elevation of the

596 Calcite Compensation Depth in response to reduced oceanic pH (Tyrrell 2011),

597 producing a carbonate dissolution layer. In addition, the types of deep-sea

598 mineral extraction planned, if put into practice (of manganese nodules, for

599 instance), will cause widespread and distinct physical and biological

600 modification.

601

602

603 Duration of the Anthropocene: the long-term perspective

604

605 The complexities of diachronous event and process boundaries and scale

606 dependence effects, visible today, will largely or wholly disappear in any

607 consideration of far future perspective.

608

609 We do not consider the Anthropocene as a short transitional phase to some kind

610 of post-Anthropocene interval, even were there to be a catastrophic decrease in

611 the global human population in the near future. Rather, we consider that the

612 future course of geological evolution, with both natural and human feedbacks,

613 will inevitably be shaped by the anthropogenic perturbations that have taken

614 place to date. Thus the Anthropocene has only just begun and will play out over

615 geological rather than human timescales. The Toarcian and Paleocene-Eocene

616 Thermal Maximum (PETM) (Cohen et al. 2007; Zachos et al. 2005) events may be

617 regarded as comparable, with an initial perturbation of the carbon cycle,

618 amplification by natural feedbacks including massive carbon release from

619 ground to air, modulated by astronomical pacing (Kemp et al. 2005), and slow

620 recovery over the order of 0.1-0.2 Myr. Although each of these events in detail

621 represents a succession of distinct phases, each may also be (and are, in practice)

622 regarded as a whole. 
624 In detail, the Anthropocene departs from the Toarcian and PETM models in a

625 number of ways. It is an incipient 'hyperthermal' in an icehouse rather than

626 greenhouse world, and so the ultimate sea level rise (barely begun) should give a

627 stronger transgressive signal (Rahmstorf, 2007) than that in an essentially ice-

628 free world. Indeed, if the glacial-interglacial cycle is significantly perturbed

629 (Tyrrell 2011) with ice loss that exceeds Quaternary norms, then the geologically

630 rapid transgression that followed the collapse of the end-Ordovician glaciation

631 (Brenchley et al. 1994) might be considered as a closer analogue (Zalasiewicz \&

632 Williams, in press).

633

634 The Anthropocene also has a biotic pattern where perturbations (habitat

635 clearance, predation, trans-global rather than local species invasions) are not

636 simply forced by climate and ocean chemistry; as with previous biotic

637 revolutions, these will be geologically long-lasting quantitatively (i.e. regarding

638 diversity measures) and effectively permanent qualitatively (with new lineages

639 arising from survivors and invaders) (see also Barnosky, this volume). This

640 pattern is also unique in modification by unpredictable but likely important

641 feedbacks, both planned and unplanned, within the perturbatory human system

642 (Kellie-Smith \& Cox 2011).

643

644 One might compare the scale of effects with those recently proposed (the 8.2 and

6454.2 kyr events) to subdivide the Holocene Epoch into Ages (Walker et al. 2012;

646 see also Gibbard \& Walker, this volume). As regards global climate, current

647 effects $\left(a<1\right.$ degree $C$ global temperature rise since the beginning of the $20^{\text {th }}$

648 century) might not be regarded as yet comparing with the 8.2 and 4.2 kyr events

649 in magnitude. However, near-future temperature rises are projected to

650 considerably exceed these (IPCC 2001, 2007), given the unprecedented and

651 ongoing rise in greenhouse gas levels. Other signals, though (lithostratigraphic,

652 biostratigraphic, chemostratigraphic) are already pronounced and, as an

653 ensemble, have no parallel in Earth's stratigraphic history. Debate over the

654 current formal significance of the Anthropocene will need to assess the relevant

655 importance of all the relevant signals, and this is not a trivial task. 
657 Nevertheless, the unprecedented rate of change in its early stages (within a small

658 part of a single interglacial phase) means that the lower boundary to deposits of

659 Anthropocene facies will appear synchronous globally. One may develop the

660 'superinterglacial' concept of Broecker (1987) by envisaging a variety of

661 stratigraphic signals that vary from 'event beds' (e.g. the urban lithostratigraphic

662 signal), to longer-lasting perturbations of chemical cycles and related effects on

663 global temperature and sea level, to the effectively permanent changes to the

664 course of the Earth's biotic evolution.

665

666

667

\section{Discussion}

668

669 How might the Anthropocene be characterized? Clearly, it is not simply by the

670 appearance of anthropogenic signals in the stratigraphic record, as these are

671 diachronous, locally dating back to earlier parts of the Holocene and indeed into

672 pre-Holocene deposits. Such early records have been used in favour of an 'early

673 Anthropocene' hypothesis that encompasses much of the Holocene (e.g.

674 Ruddiman 2003, 2013) and also in criticism of the attempt to define an

675 Anthropocene unit in stratigraphy at all (e.g. Gale \& Hoare 2012; Gibbard \&

676 Walker, this volume).

677

678 The key question seems to be whether the present-day Earth system now has

679 been changed (by whatever agent) sufficiently in scale and permanence to justify

680 a new geological time interval. If that is the case, one also may accept that the

681 change from a putative pre-Anthropocene to an Anthropocene state has taken

682 place non-instantaneously and diachronously. Most changes to the Earth system

683 in our planet's history have been neither instantaneous nor globally synchronous

684 (e.g. Williams et al. this volume), and most established geological time

685 boundaries have been compromises - generally vigorously debated - of one sort

686 or another. 
688 The task then becomes one of finding the most effective - or, if one prefers, the 689 least worst - criteria for defining a boundary. Then, one has to decide whether a

690 boundary so defined can function effectively to define both a unit of time (an

691 Anthropocene Epoch) and a body of strata (an Anthropocene strata). This is the

692 question we examine here. We note that the further test for a formal

693 Anthropocene - its use to both geological and arguably wider (Vidas, 2011;

694 Nature, 2012; Zalasiewicz 2013) communities - falls outside the scope of this

695 paper, as does the question - see above and Zalasiewicz et al. 2008, 2011, 2012,

696 Wolfe et al. 2013 - over whether a boundary, if agreed, is best defined by GSSP

697 ('golden spike') or GSSA (numerical date).

698

699 It is clear that the material record of a putative Anthropocene Series, even

700 considered with a 1950 CE boundary, is locally distinctive and substantial - a

701 feature reflecting the globally enhanced rates of erosion and sedimentation

702 caused by humans (Hooke, 2000; Wilkinson 2005; Syvitski \& Kettner 2011;

703 Price et al. 2011). It is in many places also effectively distinguishable from pre-

704 Anthropocene strata, on a decadal or even annual scale of resolution.

705

706 Elsewhere, though, the distinction of Anthropocene from pre-Anthropocene

707 strata is less obvious. This may be because there are no significant markers or

708 facies changes (as in desert dune strata, for instance). Or, it might reflect

709 widespread irresolvable mixing of Anthropocene and pre-Anthropocene strata,

710 through non-human bioturbation and other mixing processes (as in the deep

711 ocean). Or there may have been protracted, complex human reworking of the

712 ground (as in long-inhabited cities). Such phenomena prevent the clear,

713 unambiguous and consistent delineation of a laterally continuous 'Anthropocene

714 Series'. We may discuss them in turn as regards comparison with older

715 chronostratigraphic units.

716

717 The local inability to unambiguously assign particular units of strata to

718 chronostratigraphic units is a problem as old as is geology. One may take the

719 case of the 'Permo-Triassic', long used as a descriptive bucket label given the

720 difficulty of locating a boundary between Permian and Triassic deposits in 'red 
721 bed' deposits that lack fossils, even if it is as sharp and catastrophically founded

722 as that between the Permian and Triassic systems (and between the Palaeozoic

723 and Mesozoic Erathems). Even in less stratigraphically opaque strata,

724 chronostratigraphic boundaries, away from the reference 'golden spike' section,

725 can rarely be located within an error bar of less than a few hundred thousand

726 years (Zalasiewicz et al. 2013). Most stratigraphic research is based upon the

727 most informative and correlatable sections, but between these there are many

728 stratal units within which major chronostratigraphic boundaries are located only

729 approximately.

730

731 Similar uncertainty will certainly apply to an 'Anthropocene Series', with

732 boundaries (now being placed at a decadal/annual scale) being effectively

733 locatable in some places and more uncertainly placed in others. Hence, at least

734 qualitatively, the Anthropocene shares the correlation problems attached to

735 chronostratigraphic units generally, and it is not yet clear whether it possesses

736 these kinds of uncertainties in greater measure than do the established units of

737 the Geological Time Scale.

738

739 The problem of the disruption of superposition is rather different. This arises in

740 part out of the exceedingly short timescale of the Anthropocene (to date) and in

741 part out of complex, intermingled sedimentary geometries commonly created by

742 human activity, where clear principles of superposition cannot be applied. This

743 creates situations that archaeologists, for instance, are more familiar with, in

744 discriminating numerous successive historical events within geometrically

745 complex deposits (Edgeworth this volume) and on palimpsest surfaces (where

746 the evidence from different phases of human history is preserved upon

747 essentially two-dimensional surfaces).

748

749 The practice of basing chronostratigraphic subdivision upon the principle of

750 superposition reflects the tendency on Earth for thick successions of strata to

751 have built up, virtually since the origin of the planet. For most of the geological

752 record it is an effective means to build and operate the geological time scale, and

753 in older rocks, where stratigraphic uncertainties are measured in millions of 
754 years, then superpositional blurring through bioturbation and allied processes

755 may be regarded as negligible. In such circumstances, chronostratigraphy and

756 geochronology have operated in parallel, in their long-established 'dual

757 hierarchy'.

758

759 However, at brief geological time scales and/or when extremely fine temporal

760 resolution is sought, disruption of superpositional relationships may become a

761 practical, rather than theoretical problem. This is already the case in the

762 discrimination of high-resolution climate histories from deep sea floor deposits,

763 where those strata with the highest sedimentation rates (and therefore least

764 prone to bioturbational mixing) are actively sought. This phenomenon is, hence,

765 most acutely expressed in the Anthropocene, with its extremely short timescale

766 exacerbated by its peculiarly human-made complex stratal geometries. It might

767 regarded as a problem as much inherent of chronostratigraphic practice as it is

768 of the Anthropocene.

769

770 Nevertheless, despite the complicating effects of these various processes, we

771 propose that a reasonably consistent Holocene-Anthropocene boundary placed

772 at 1950 CE might be effectively traceable over large areas in both marine and

773 non-marine settings. Attempts to consistently trace and delineate such a unit

774 would reveal the extent to which this proposal is true. They would also help in

775 the understanding of the extraordinary episode of history - whether formalised

776 in stratigraphy or not - which the Earth is currently experiencing.

777

778

779

\section{Conclusions}

780

781 - A material 'Anthropocene Series' might be defined with a historically

782 recent boundary at $\sim 1950 \mathrm{CE}$, characterised by time proxies such as artificial

783 radionuclides, biostratigraphic changes and human-made novel materials such

784 as plastics and uncombined aluminium. It locally forms substantial, distinct and

785 correlatable sediment bodies in both terrestrial and marine realms. 
- Locally, too, Anthropocene deposits so defined are difficult to recognise and correlate for want of appropriate time markers to fix the boundary. These are analogous to stratigraphically indeterminate deposits in the older stratigraphic record.

792 - Commonly, also, Anthropocene deposits are difficult to separately

793 recognise as distinct units because of intermixing, for instance by human or no-

794 human bioturbation, reflecting the very short duration of the Anthropocene.

795 This may be regarded as a problem inherent in very high-resolution

796 chronostratigraphy as much as one of the Anthropocene.

797

798

- $\quad$ Attempts to better delineate and analyse the material expression of the 799 Anthropocene will increase our understanding of the phenomenon as a whole.

800

801

802

803

Acknowledgements: Colin Waters publishes with the permission of the

804

Executive Director, British Geological Survey, Natural Environment Research

805

806

807

References

808

809

AlLEN, J.R.L. 1988. Modern-period muddy sediments in the Severn Estuary 810

Council. We thank Will Steffen and Mike Ellis for thorough and helpful reviews. (southwestern U.K.): a pollutant-based model for dating and correlation. Sedimentary Geology, 58, 1-21.

Al-Rousan, S., Pätzold, J., Al-Moghrabi, S., \& Wefer, G., 2004, Invasion of anthropogenic $\mathrm{CO}_{2}$ recorded in planktonic foraminifera from the northern Gulf of Aquaba. International Journal of Earth Sciences, 93, 1066-1076, doi: 10.1007/s00531-004-0433-4.

ANDERSON, D.M. 2001. Attenuation of millenial-scale events by bioturbation in marine sediments. Palaeoceanography, 16, 352-357.

APpLEBY, P.G. 2008. Three decades of dating recent sediments by fallout radionuclides: a review. The Holocene, 18 (1), 83-93. 
820

821

822

823

824

825

826

827

828

829

830

831

832

833

834

835

836

837

838

839

840

841

842

843

844

845

846

847

848

849

850

851

852

Autin, W.J. \& HolBRooK, J.M. 2012. Is the Anthropocene an issue of stratigraphy or pop culture? GSA Today, 22 (7), 60-61.

BACON, A.R., Richter, D. DEB, BIERMAN, P.R. \& Rood, D.H. 2012. Coupling meteoric ${ }^{10} \mathrm{Be}$ with pedogenic losses of ${ }^{9} \mathrm{Be}$ to improve soil residence times on an ancient North American interfluve. Geology, 40, 847-850.

BARNOSKY, A.D. 2008. Megafauna biomass tradeoff as a driver of Quaternary and future extinctions. Proceedings of the National Academy of Sciences USA, 105(suppl. 1),11543-11548.

BARNOSKY, A.D. 2013. Palaeontological evidence for defining the Anthropocene. In: A Stratigraphical Basis for the Anthropocene. Waters et al. (eds)

Barnosky, A.D., Matzke, N., Tomiya, S., Wogan, G.O.U., SWARTZ, B., Quental, T., Marshall, C., McGuire, J.L., Lindsey, E.L., Maguire, K.C., Mersey, B. \& Ferrer, E.A. 2011. Has the Earth's sixth mass extinction already arrived? Nature, 471, 51-57.

Barnosky, A.D., Hadly, E.A., Bascompte, J., Berlow, E.L., Brown, J.H., Fortelius, M., Getz, W.M., Harte, J., Hastings, A., Marquet, P.A., Martinez, N.D., Mooers, A., Roopnarine, P., VermeeiJ, G., Williams, J.W., Gillespie, R., KitZes, J., MarshalL, C., Matzke, N., Mindell, D.P., Revilla, R. \& SMith, A.B. 2012. Approaching a state-shift in the biosphere. Nature, 486, 52-56.

BOLlHÖFER, A. \& Rosman, K.J.R. 2000. Isotopic source signatures for atmospheric lead: The Southern Hemisphere. Geochimica Cosmochimica Acta, 64, 32513262.

Brenchley, P.J., MARshall, J.D., CARDEn, G.A.F., Robertson, D.B.R., LONG, D.G.F., MeidLA, T., HiNTS, L. \& AndERson, T.F. 1994. Bathymetric and isotopic evidence for a short-lived Late Ordovician glaciation in a greenhouse period. Geology, 22, 295-298.

Brown, A.G., Toms, P., CARey, C. \& Rhodes, E. 2013. Geomorphology of the Anthropocene: time-transgressive discontinuities of human-induced alluviation. Anthropocene 1, doi: 10.1016/j.ancene.2013.06.002.

BroeCKER, W.S. 1987. How to build a habitable planet. New York, Eldigio Press, 291 pp.

Buesseler, K.O. and 18 others. 2007. Revisiting carbon flux through the ocean's twilight zone. Science, 316, 567-570. 
853 CARTER, R.M. 2007, Stratigraphy into the $21^{\text {st }}$ century. Stratigraphy, 4, 187-194.

854 Certini, G. \& ScAlenghe, R. 2011. Anthropogenic soils are the golden spikes for the 855 Anthropocene. The Holocene, 21, 1269-1274

Cohen, A.S., CoE, A.L. \& KemP, D.B. 2007. The Late Palaeocene-Early Eocene and 857 Toarcian (Early Jurassic) carbon isotope excursions: a comparison of their time scales, associated environmental changes, causes and consequences. Journal of the Geological Society, London, 164, 1093-1108.

860 CRutzen, P.J. 2002, Geology of Mankind. Nature, 415, 23.

861 Crutzen, P.J. \& Stoermer, E.F. 2000, The ‘Anthropocene’. Global Change $862 \quad$ Newsletter, 41, 17-18.

863

Dounas, C., Davies, I., Triantafyllou, G., Koulouri, P., Petihakis, G., 864 Arvanitidis, C., Sourlatzis, G. \& Eleftheriou, A. 2007. Large-scale 865 impacts of bottom trawling on shelf primary productivity. Continental Shelf

866 Research, 27, 2198-2210.

EDGEWORTH, M. 2013. Archaeological stratigraphy and artificial ground. In: A Stratigraphical Basis for the Anthropocene. Waters et al. (eds).

EDWARDS, K.J. \& WhitTington, G. 2001. Lake sediments, erosion and landscape 870 change during the Holocene in Britain and Ireland. Catena, 42, 143-173.

871

ELLIS, E.C. 2011. Anthropogenic transformation of the terrestrial biosphere.

872 Philosophical Transactions of the Royal Society, A369, 1010-1035.

873 Ellis, E.C., ANTILL, E.C. \& KREFT, H. 2012. All Is Not Loss: Plant Biodiversity in 874 the Anthropocene. PLoS ONE, 7, e30535.

875 Elsig, J., Schmitt, J., Leuenberger, D., Schneider, R., Eyer, M., Leuenberger, 876 M., JoOs, F., Fischer, H. \& STOCKER, T.F. 2009. Stable isotope constraints on 877 878 Holocene carbon cycle changes from an Antarctic ice core. Nature, 461, 507-

879 510.

880

FINNEY 2013 In: A Stratigraphical Basis for the Anthropocene. Waters et al. (eds).

881

882

Ford, J.R., Price, S.J., COOPER, A.H. \& WATERS, C.N. An assessment of

883 Gale, S.J. \& HoARe, P.G. 2012. The stratigraphic status of the Anthropocene. The 884 Holocene, DOI:10.1177/0959683612449764. 
885

886

887

888

889

890

891

892

893

894

895

896

897

898

899

900

901

902

903

904

905

906

907

908

909

910

911

912

913

914

915

916

917

GALUSZKA et al. this volume. Assessing the Anthropocene with geochemical methods. In: A Stratigraphical Basis for the Anthropocene. Waters et al. (eds).

Gattuso, J. P., Smith, S. V., Hogan, C. M. \& Duffy, J. E. 2009 ‘Coastal zone’. In Encyclopedia of Earth (ed. C. J. Cleveland). Washington, DC: Environmental Information Coalition, National Council for Science and the Environment. (First published in the Encyclopedia of Earth. See http://www.eoearth.org/article/Coastal_zone.)

Gibbard, P.L. \& WALKer, M.J.C. 2013. The term 'Anthropocene' in the context of formal geological classification. In: A Stratigraphical Basis for the Anthropocene. Waters et al. (eds)

Gosse, J.C. \& PHILLIPS, F.M. 2001. Terrestrial in situ cosmogenic nuclides: theory and application. Quaternary Science Reviews, 20, 1475-1560.

GoudiE, A.S. 2009. Dust storms: Recent developments. Journal of Environmental Management, 90, 89-94.

Gradstein, F., OgG, G., Schmitz, M. \& OGg, G. (eds) A Geological Time Scale 2012. Elsevier, 1144 pp.

HAFF, P. this volume. Technology as a geological phenomenon: Implications for human well-being. In: A Stratigraphical Basis for the Anthropocene. Waters et al. (eds).

Hancock, G.J., Leslie, C., Everett, S.E., Tims, S.G., Brunskill, G.J. \& Haese, R. 2011. Plutonium as a chronomarker in Australian and New Zealand sediments: a comparison with ${ }^{137}$ Cs. Journal of Environmental Radioactivity, 102, 919929.

HAY, W.W. 2013. Experimenting on a small planet: a scholarly entertainment. Springer-Verlag: Berlin Heidelberg, 983 pp.

Higgins, S., Overeem, I., TANAKA, A. \& SyvitSKi, J.P.M. 2013. Land subsidence at aquaculture facilities in the Yellow River delta, China. Journal of Geophysical Research 40, 3898-3902.

Holtgrieve, G.W., Schindler, D.E., HobBs, W.O., LeAvitT, P.R., WARD, E.J., Bunting, L., Chen, G., Finney, B.P., Gregory-Eaves, I., Holmgren, S., LiSAC, M.J., Lisi, P.J., Nydick, K., Rogers, L.A., SAROS, J.E., SElbiE, D.T., Shapley, M.D., WAlsh, P.B. \& WolfE, A.P. 2011. A coherent signature of 
anthropogenic nitrogen deposition to remote watersheds of the northern hemisphere. Science, 334, 1546-1548.

HoOKe, R. LEB., 2000, On the history of humans as geomorphic agents. Geology 28: 843-846.

IPCC (Intergovermental Panel on Climate Change) 2001. Climate Change 2001: The Scientific Basis. Contribution of Working Group I to the Third Assessment Report of the Intergovernmental Panel on Climate Change. Houghton, J.T.,Y., Ding, D.J., Griggs, M., Noguer, P.J., van der Linden, X., Dai, K., Maskell \& Johnson, C.A. (eds). Cambridge University Press, Cambridge, United Kingdom and New York, NY, USA, 881pp.

IPCC (Intergovernmental Panel on Climate Change). 2007. Climate change 2007: synthesis report. Summary for policy makers. Available at: http://www.ipcc.ch/SPM2feb07.pdf.

KaPlan, J.O., KRUMHARDT, K., Ellis, E.C. RudDiman, W.F., LEMMEN, C. \& GOLDEWIJK, K.K. 2011. Holocene carbon emissions as a result of anthropogenic land cover change. The Holocene, 21 (5), 775-791.

Kellie-Smith, O. \& CoX, P.M. 2011. Emergent dynamics of the climate-economy system in the Anthropocene. Philosophical Transactions of the Royal Society, A369, 868-886.

KemP, D.B., CoE, A.L., COHEN, A.S. \& SCHWARK, L. 2005. Astronomical pacing of methane release in the Early Jurassic period. Nature, 437, 396-399.

KRAMER, N., WOHL, E.E. \& HARRY, D.L. 2011. Using ground penetrating radar to 'unearth' buried beaver dams. Geology, 40, 43-46.

Kruge, M. A. 1999. Molecular organic geochemistry of New York Bight sediments. Sources of biogenic organic matter and polycyclic aromatic hydrocarbons. Northeastern Geology and Environmental Sciences, 21, 121-128.

KulKarni, A.V., Bahuguna, I.M., Rathore, B.P., Singh, S.K., RANDHAWA, S.S., SoOD, R.K. \& DHAR, S. 2007. Glacial retreat in Himalya using Indian Remote Sensing satellite data. Current Science, 92, 69-74.

LARMER, B. 2010. Shanghai Dreams. National Geographic, March 2010, 124-141

LEWIN, J. 2012. Enlightenment and the GM floodplain. Earth Surface Processes and Landforms. DOI:10.1002/esp.3230

MalAKOFF, D. 2002. Trawling’s a drag for marine life, say studies. Science 298, 2123. 
952

953

954

955

956

957

958

959

960

961

962

963

964

965

966

967

968

969

970

971

972

973

974

975

976

977

978

979

980

981

982

983

984

MANN, M.E. 2002. Little Ice Age. In: The Earth system: physical and chemical dimensions of global environmental change. MacCracken, M.C. \& Perry, J.S. (eds). Encyclopedia of Global Environmental Change, Volume 1, 504-509. (Chichester: John Wiley \& Sons, Ltd.) ISBN 0-471-97796-9.

Marshall, W.A., Gehrels, W.R., Garnett, M.H., Freeman, S.P.H.T., Maden, C. \& XU, SHENG, 2007, The use of 'bomb spike' calibration and high-precision AMS 14C analyses to date salt marsh sediments deposited during the last three centuries. Quaternary Research, 68, 325-337.

Merrits, D., Walter, R., Rahnis, M., Hartranft, J., Cox, S., Gellis, A., Potter, N., Hilgartner, W., LANGland, M., MAnion, L., LipPincott, C., SiddiQui, S., Rehman, Z., Scheid, C., KratZ, L., Shilling, A., JenschKe, M., Datin, C., Cranmer, E., ReEd, A., MAtuszewski, D., Voli, M., Ohlson, E., Neugebauer, A., Ahamed, A., Neal, C., Winter, A. \& Becker, C. 2011. Anthropocene streams and base-level controls from historic dams in the unglaciated mid-Atlantic region, USA. Philosophical Transactions of the Royal Society, A369, 976-1009.

Moulin, C. \& ChiApello, I. 2006. Impact of human-induced desertification on the intensification of Sahel dust emission and export over the last decades. Geophysical Research Letters, 33, L18808.

Myers, R.A. \& WorM, B., 2003, Rapid worldwide depletion of predatory fish communities. Nature, 423, 280-283.

NATURE (editorial) 2011. The human epoch. Nature, 473, 254.

NAYAR, A. 2009. When the ice melts. Nature, 461, 1042-1046.

New, M.G., Liverman, D.M., Betts, R.A., Anderson, K.L. \& West, C.C. (eds) 2011. Four degrees and beyond: the potential of a global temperature increase of four degrees and its implications. Philosophical Transactions of the Royal Society, A369.

PAlAnQues, A., Guillén, J. \& Puig, P. 2001. Impact of bottom trawling on water turbidity and muddy sediment of an unfished continental shelf. Limnology and Oceanography, 46, 1100-1110..

Poirier, C., Chaumillon, E. \& ARnaud, F. 2011. Siltation of river-influenced coastal environments: Respective impact of late Holocene land use and highfrequency climate changes. Marine Geology, 290, 51-62. 
985 PRICE, S.J., FORD, J.R., COOPER, A.H. \& NEAL, C. 2011. Humans as major geological 986 and geomorphological agents in the Anthropocene: the significance of artificial 987 988 ground in Great Britain. Philosophical Transactions of the Royal Society, A369, 1056-1084.

Puig, P., CAnals, M., Company, J.B., Martin, J., AmBlas, D., LAStras, G., PAlANQUes, A. \& CAlAfat, A.M. 2012. Ploughing the deep sea floor. Nature, 489, 286-289.

RAHMSTORF, S., 2007, A semi-empirical approach to projecting future sea-level rise. Science, 315, 368-370.

Ramirez-Llodra, E., Tyler, P.A., BAKer, M.C., Bergstad, O.A., Clark, M.R., Escobar, E., Levin, L.A. MEnot, L., Rowden, A.A., SMith, C.R. \& VAN Dover, C.L. 2011. Man and the Last Great Wilderness: Human Impact on the Deep Sea. Plos One 6 (8), e22588, 1-25.

Remane, J., Bassett, M.G., Cowie, J.W., Gohrbandt, K.H., LAne, H.R., Michelson, O. \& NAiwen, W. 1996. Revised guidelines for the establishment of global chronostratigraphic standards by the International Commission on Stratigraphy (ICS). Episodes 19, 77-81.

REVKIN, A. 1992. Global warming: understanding the forecast. New York, NY: American Museumn of Natural History, Environmental Defense Fund, Abbeville Press.

RiCHTER, D. 2007. Humanity's transformation of Earth’s soil: pedology's new frontier. Soil Science 172, 957-967.

RoBERTS, C. 2007. The unnatural history of the sea. Island Press.

Robison, B.H., REISENBICHLER, K.R. \& SHERLOCK, R.E. 2005. Giant larvacean houses: rapid carbon transport to the deep sea floor. Science, 308, 1609-1611.

Rockström, J., Steffen, W., Noone, K., Persson, Å, Chapin, III, F.S., LAmbin, E.F., LENTON, T.M., SCHEFFER, M., FOLKE, C., SCHELlNHUBER, H.J., NYKVIST, B., DE Wit, C.A., Hughes, T., VAN DER LeEuw, S., Rodhe, H., SörLin, S., SNyder, P.K., Costanza, R., Svedin, U., FALKenMark, M., KARLberG, L., Corell, R.W., FABry, V.J., HANSEN, J., WALKer, B., LiVERMan, D., Richardson, K., CRUtZen, P. \& Foley, J.A. 2009. A safe operating space for humanity. Nature, 461, 472-475.

RudDiman, W F. 2003. The Anthropogenic Greenhouse Era began thousands of Years Ago. Climatic Change, 61, 261-293. 
1019 RudDiman, W.F. 2013. Anthropocene. Annual Review of Earth and Planetary

1020

1021

1022

1023

1024

1025

1026

1027

1028

1029

1030

1031

1032

1033

1034

1035

1036

1037

1038

1039

1040

1041

1042

1043

1044

1045

1046

1047

1048

1049

1050

1051

1052
Sciences. DOI: 10.1146/annurev-earth-050212-123944

ShePpARD, C. 2006. Trawling the sea bed. Marine Pollution Bulletin, 52, 831-835.

Shoulders, S.J. \& CARTwright, J.A., 2004, Constraining the depth and timing of large-scale conical sandstone intrusions. Geology, 32, 661-664.

SMith, D.M., ZaLASIEWICZ, J.A., Williams, M., WiLkinson, I., REDDinG, M. \& BEGG, C. 2010. Holocene drainage of the English Fenland: roddons and their environmental significance. Proceedings of the Geologists’ Association, 121, 256-269.

STANLEY, D.J. 1996. Nile delta: extreme case of sediment entrapment on a delta plain and consequent coastal land loss. Marine Geology, 129, 189-195.

Steffen, W., Crutzen, P.J. \& McNeill, J.R., 2007, The Anthropocene: are humans now overwhelming the great forces of Nature? Ambio, 36, 614-621.

StefFen, W.Å.P, Deutsch, L., Zalasiewicz, J., Williams, M., Richardson, K., Crumley, C., Crutzen, P., Folke, C., Gordon, L., Molina, M., RAMANATHAN, V., ROCKSTRÖM, J., SCHEFFER, M., SCHELlNHUBER, J. \& SVEDIN, U. 2011. The Anthropocene: from global change to planetary stewardship. Ambio, 40, 739-761.

SYVITSKI, J.P.M. \& KeTTNER, A. 2011. Sediment flux and the Anthropocene. Philosophical Transactions of the Royal Society, A369, 957-975.

TAnaKa, K.L. \& Hartmann, W.K. 2012. Ch. 15: The Planetary Time Scale. In: The Geological Time Scale 2012. Gradstein, F.M., OGG, J., Schmitz, M. \& OGG, G. (eds), 275-298. Elsevier.

TÖRnQvist, T E, Wallace, D J, Storms, J E A, Wallinga, J, VAn Dam, R L, Blaauw, M, Derksen, M S, Klerks, C J W, Meijneken, C, \& Snijders, E M A. 2008. Mississippi Delta subsidence primarily caused by compaction of Holocene strata. Nature Geoscience, 1, 173-176.

Tyrrell, T. 2011. Anthropogenic modification of the oceans. Philosophical Transactions of the Royal Society, A369, 887-908.

VAne, C.H., Chenery, S.R., Harrison, I., Kim, A.W., Moss-Hayes, V. \& Jones, D.G. 2011. Chemical signatures of the Anthropocene in the Clyde estuary, UK: sediment-hosted Pb, 207/206 Pb, total petroleum hydrocarbon and polychlorinated biphenyl pollution records. Philosophical Transactions of the Royal Society, A369, 1085-1111. 
1053 VIDAS, D. 2011. The Anthropocene and the international law of the sea. Philosophical

1054 Transactions of the Royal Society, A369, 909-925.

1055 Walker, M., Johnsen, S., Rasmussen, S.O., Steffensen, J.P., PopP, T., GibBard,

1056 P., Hoek, W., Lowe, J., BJÖRck, S., Cwynar, L., Hughen, K., Kershaw, P.,

1057 Kromer, B., LiTt, T., LOWE, D.J., NAKAgAwa, T., NeWNHAM, R. \&

1058 SCHWANDER, J. 2009. Formal definition and dating of the GSSP (Global

1059 Stratotype Section and Point) for the base of the Holocene using the Greenland

1060 NGRIP ice core, and selected auxiliary records. Journal of Quaternary Science,

$1061 \quad 24,3-17$.

1062

WAlKer, M.J.C., Berkelhammer, M., BJÖRK, S., CWYnar, L.C., Fisher, D.A.,

1063 LONG, A.J. \& LOWE, J.J. 2012. Formal subdivision of the Holocene

1064

1065

1066

1067

1068

1069

1070

1071

1072

Series/Epoch: a discussion paper by a Working Group of INTIMATE

(Integration of ice-core, marine and terrestrial records) and the Subcommission on Quaternary Stratigraphy (International Commission on Stratigraphy). Journal of Quaternary Studies doi: 10.1002/jqs.2565.

WilKinson, B.H., 2005, Humans as geologic agents: A deep-time perspective. Geology, 33, 161-164.

WiLKINSON, I.P. et al. this volume. Micropalaeontological signatures of the Anthropocene. In: A Stratigraphical Basis for the Anthropocene. Waters et al. (eds).

Williams, M., et al. This volume.

Wolfe, A.P., Hobbs, W.O., Birks, H.W., Briner, J.P., Holmgren, S.W., Ingolfssón, Ó., Kaushal, S.J., Miller, G.H., PAgani, M., SARos, J.E. \& VINEBROOKE, R.D. 2013. Stratigraphic expressions of the HoloceneAnthropocene transition revealed in sediments from remote lakes. EarthScience Reviews, 116, 17-34.

YAN, P., SHI, P., GAO, S., ChEn, L., ZHANG, X. \& BAI, L. 2002. ${ }^{137}$ Cs dating of lacustrine sediments and human impacts on Dalian Lake, Qinghai Province, China. Catena, 47, 91-99.

Zachos, J.C., RöHl, U., Schellenberg, S.A., SluiJs, A., Hodell, D.A., Kelly, D.C., Thomas, E., Nicolo, M., RafFi, I., Lourens, L.J., McCarren, H. \& Kroon, D., 2005, Rapid acidification of the ocean during the Paleocene-

ZALASIEWICZ, J. 2013. The epoch of humans. Nature Geoscience 6, 8-9. 
Zalasiewicz, J.A., Smith, A, Brenchley, P., Evans, J., Knox, R., Riley, N., Gale, A., Rushton, A., Gibbard, P., Hesselbo, S., Marshall, J., OAtes, M., RaWson, P. \& Trewin, N. 2004. Simplifying the stratigraphy of time. Geology, 32, 1-4.

Zalasiewicz, J., Williams, M , Smith, A., BARry, T.L., Bown, P.R., RAwSON, P., Brenchley, P., Cantrill, D., Coe, A.E., Cope, J.C.W., Gale, A., GibBard, P.L., Gregory, F.J., Hounslow, M., Knox, R., Powell, P., Waters, C., Marshall, J., OAtes \& StOne, P. 2008. Are we now living in the Anthropocene? GSA Today, 18 (2), 4-8.

Zalasiewicz, J., Williams M, Fortey, R.A., Smith, A.G., Barry, T.L. Coe, A.L., Bown, P.R., Gale, A., GiBBARD, P.L., Gregory, F.J., HounslOW, M.W., Kerr, A.C., Pearson, P., Knox, R., Powell’ J., Waters, C., Marshall, J., OAtes, M., Rawson' P. \& Stone, P. 2011. Stratigraphy of the Anthropocene. Philosophical Transactions of the Royal Society, A369, 1036-1055.

Zalasiewicz, J., Crutzen, P.J. \& Steffen, W. 2012. Anthropocene. Chapter 32 (pp. 1033-1040) in A Geological Time Scale 2012 (ed. Gradstein, F., OgG, G., SchmiTZ, M. \& OGG, G.). Elsevier, 1144 pp.

Zalasiewicz, J., Williams, M , Smith, A., Barry, T.L., Bown, P.R., Rawson, P., Brenchley, P., CANTRill, D., Gale, A., GibBard, P.L., Gregory, F.J., Hounslow, M., Knox, R., Powell, P., Waters, C., Marshall, J., OAtes, StOne, P. \& TREWIN, N. 2007. The scale-dependence of strata-time relations: implications for stratigraphic classification. Stratigraphy, 4, 139-144.

Zalasiewicz, J., Cita, M.B., Hilgen, F., Pratt, B.R., Strasser, A. Thierry, J., WEISSERT, H. 2013. Chronostratigraphy and geochronology: a proposed realignment. GSA Today, 23 (3), 4-8.

ZALASIEWICZ, J., KrYZA, R. \& Williams, M. this volume. The mineral signature of the Anthropocene. In: A Stratigraphical Basis for the Anthropocene. Waters et al. (eds).

ZaLASIEWICZ, J. \& WiLliams, M. In press. The Anthropocene: a comparison with the Ordovician-Silurian boundary. Rendiconti Lincei.

\section{List of figures}


1123 Figure 1. Comparison of lengths of epochs from the mid-Cenozoic to the present,

1124 showing progressive shortening in time span. Dates from Gradstein et al. 2012.

1125

1126 Fig. 2. The rapid mid-twentieth century growth of Shanghai, as an example of the 1127 formation of a distinct, extensive sedimentary facies that may be referred to a putative

1128 Anthropocene Series. Information from Larmer (2010) and Map of Central Shanghai, 1129 printed by the British War Office/US Army Map Service in 1935.

1130 


\section{$2.588 \mathrm{Ma}$}

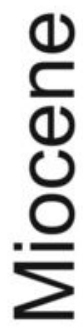




\section{$2.588 \mathrm{Ma}$}

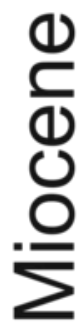


